\title{
THE CROWN'S FIDUCIARY DUTIES TO ABORIGINAL PEOPLES AS AN ASPECT OF CLIMATE JUSTICE
}

\section{Erika Chamberlain*}

Rapid climate change in the arctic is threatening the life, health and cultural traditions of the Inuit. Although they are among the least responsible for climate change, they are suffering disproportionately from its negative effects. In particular, the inherent link between Inuit land and culture means that their traditional practices are being threatened along with the arctic environment. However, their efforts to obtain redress from those responsible for greenhouse gas emissions have so far been unsuccessful. Claims in common law public nuisance have been plagued by issues of standing, justiciability and causation, and claims at international law are difficult to prove and enforce. It seems that a different approach may be required.

This article examines whether the Crown's fiduciary obligation toward Canada's Aboriginal peoples might provide a useful conceptual framework for addressing arctic climate change. Although this obligation is typically applied in situations involving Aboriginal lands or distinctive cultural practices, it can arguably be invoked to protect the traditional subsistence lifestyle of the Inuit. Both the fiduciary obligations and the honour of the Crown require a minimum level of consultation and accommodation where significant Aboriginal interests are threatened. This could translate into an obligation to, at least, assist the Inuit in adapting to the changing arctic environment and preserving cultural practices to the extent possible.

Les changements climatiques rapides dans l'Arctique menacent la vie, la santé et les traditions culturelles des Inuits. Même s'ils sont parmi les peuples les moins responsables de ces changements climatiques, ils souffrent de façon disproportionnée des effets négatifs de ces changements. Tout particulièrement, comme la culture inuite est intrinsèquement liée à la terre, les pratiques traditionnelles inuites sont menacées en même temps que l'environnement arctique. Par ailleurs, les efforts des Inuits pour obtenir réparation de la part

* $\quad$ Faculty of Law, Western University. The author wishes to thank Professors Michael Coyle and Sara Seck for their helpful discussions, and Adam Jacobs for his research assistance. The research underlying this article was funded by an International Research Linkages Grant from the International Council for Canadian Studies, Canadian Department of Foreign Affairs and International Trade. The grant also allowed the author to visit Australia to discuss the effects of climate change on indigenous peoples with colleagues at the Queensland University of Technology and Monash University. 
des responsables des émissions de gaz à effet de serre sont restés vains. Les demandes fondées sur la nuisance en common law se sont heurtées aux questions relatives à la qualité pour agir, à la justiciabilité et à la causalité; de plus, en droit international, il est difficile de prouver et de faire valoir des réclamations. Il semble clair qu'une approche différente s'impose.

Le présent article examine si l'obligation fiduciale de l'État envers les peuples autochtones du Canada pourrait constituer un cadre juridique utile pour traiter des changements climatiques dans l'Arctique. Bien que cette obligation soit systématiquement reconnue dans les situations concernant des terres autochtones ou des pratiques culturelles distinctives, il est permis de penser qu'elle pourrait être invoquée pour protéger le mode de subsistance traditionnelle des Inuits. Tant les obligations fiduciales que l'honneur de la Couronne requièrent un degré minimal de consultation et d'accommodement lorsque des intérêts autochtones significatifs sont menacés. Cela pourrait se traduire par une obligation minimale d'aider les Inuits à s'adapter à l'environnement arctique changeant et à préserver leurs pratiques culturelles dans la mesure du possible.

\section{INTRODUCTION}

The growing field of climate justice explores the interaction of climate change, human rights, and disadvantaged groups. It recognizes that certain populations, whether because of poverty, geography, culture or political limitations, often suffer disproportionate effects from climate change. 'This includes, for example, island communities that risk losing their lands due to rising sea levels, ${ }^{2}$ and the poorer residents of the southern United States, who bore the brunt of the devastation caused by Hurricane Katrina. ${ }^{3}$ Proponents of climate justice argue that the strategies for managing climate change must consider their impact on the social welfare and human rights of such vulnerable groups.

One of the most promising areas for climate justice advocates is the plight of the Inuit in the arctic regions of Canada and Alaska. ${ }^{4}$ The Inuit are among those

1 See e.g. R Tsosie, "Indigenous People and Environmental Justice: The Impact of Climate Change" (2007) 78 U Colo L Rev 1625; M Burkett, "Just Solutions to Climate Change: A Climate Justice Proposal for a Domestic Clean Development Mechanism" (2008) 56 Buffalo L Rev 169. Climate justice can be seen as a subcategory of the longer-established environmental justice movement.

2 See e.g. S Tully, "The Contribution of Human Rights as an Additional Perspective on Climate Change Impacts within the Pacific" (2007) 5 New Zealand Journal of Public and International Law 169; Submission of the Maldives to the Office of the High Commissioner for Human Rights, made under Resolution HR 7/23 (25 September 2008).

3 Burkett, supra note 1 at 184-88. See also Comer v Murphy Oil, 607 F 3d 1049 (5th Cir 2010),

where it was alleged that greenhouse gas emissions worsened the effects of the storm. Through a rather bizarre procedural route, the court essentially upheld the district court judge's decision that the claim was barred by the political question doctrine.

4 See generally JH Knox, "Climate Change and Human Rights Law" (2009) 50 Va J Int'l L 163; D Goldberg \& M Wagner, "Human Rights Litigation to Protect the Peoples of the Arctic" (2004) 98 
least responsible for greenhouse gas emissions, but they stand to suffer worse than most from the effects of climate change. Melting sea ice threatens the territory and wildlife upon which the Inuit have based their subsistence lifestyle for many generations. ${ }^{5}$ Changing weather patterns have undermined traditional hunting strategies and made it difficult to plan expeditions. Increasingly violent storms are eroding shorelines and may force some communities to relocate. In short, not only are the health and safety of the Inuit at risk, but also their sense of community, distinctive culture, and historic way of life.

The Inuit are thus uniquely positioned from the perspective of climate justice. However, their efforts to obtain redress through traditional legal systems have so far been thwarted. In Native Village of Kivalina $v$ ExxonMobil Corporation, ${ }^{6}$ the plaintiffs brought a claim in public nuisance with respect to melting sea ice and coastline erosion, which will allegedly require the village to relocate. Their claim was dismissed by a District Court Judge on the basis of the political question doctrine and the plaintiffs' lack of standing. Similarly, the Inter-American Commission on Human Rights stated that it was not presently possible to evaluate a claim by the Inuit Circumpolar Conference that the United States had violated the American Declaration of the Rights and Duties of $\mathrm{Man}^{7}$ through its failure to abate greenhouse gas emissions. ${ }^{8}$ These failed claims, coupled with the generally poor track record of tort claims based on climate change, ${ }^{9}$ has led some scholars to suggest that the Inuit face an uphill battle in achieving climate justice through litigation. ${ }^{10}$

This article is not intended to promote the viability of climate change litigation in international law or the common law of public nuisance, which admittedly face difficult issues of standing, causation and trans-boundary responsibility. Rather, this paper examines whether Canadian Inuit can argue that the fiduciary duty owed to them by the federal Crown entails an obligation to protect them from the

Proceedings of the Annual Meeting of the American Society of International Law 227; S Nuffer, "Human Rights Violations and Climate Change: The Last Days of the Inuit People?" (2010) 37 Rutgers Law Record 182.

5 See Intergovernmental Panel on Climate Change, Fourth Assessment Report: Climate Change 2007: Impacts, Adaptation and Vulnerability (2007), ch 15.

6663 F Supp 2d 863 (Dist Ct 2009), aff'd on other grounds 696 F 3d 849 (9th Cir 2012) [Kivalina].

7 American Declaration of the Rights and Duties of Man, Res XXX, adopted by the Ninth International Conference of American States, Bogota, Colombia (2 May 1948), reprinted in (1949) 43 Am J Intl L Supplement 133 [American Declaration].

8 See S Watt-Cloutier, Petition to the Inter-American Commission on Human Rights Seeking Relief from Violations Resulting from Global Warming Caused by Acts and Omissions of the United States (7 Dec 2005) [Inuit Petition]. The Commission held a hearing in 2007, but has done nothing since. See Knox, supra note 4 at 192.

9 Most recently, the United States Supreme Court decision in American Electric Power Company Inc et al v Connecticut et al, $131 \mathrm{~S} \mathrm{Ct} 2527$ (2011) [AEP v Connecticut] found that a public nuisance claim against greenhouse gas emitters was barred by the preemption doctrine, because such emissions can be regulated through the Clean Air Act.

10 See SL Hsu, "A Realistic Evaluation of Climate Change Litigation Through the Lens of a Hypothetical Lawsuit" (2011) 79 U Colo L Rev 101. See also generally, J Benidickson \& H McLeod-Kilmurray, "Canada" in J Kotzé \& Alexander R Paterson, eds, The Role of the Judiciary in Environmental Governance: Comparative Perspectives (The Netherlands: Kluwer Law International, 2009); S Tully, "Like Oil and Water: A Sceptical Appraisal of Climate Change and Human Rights" (2008) 15 Australian International Law Journal 213; Eric A Posner \& Cass R Sunstein, "Climate Change Justice" (2007) 96 Geo LJ 1565. 
harmful effects of climate change. The Crown's fiduciary relationship with Canada's Aboriginal peoples has typically been applied to acts of administration, legislation, land use, and treaty interpretation. Nevertheless, because that relationship is sui generis, and because fiduciaries are charged with an obligation to act in their beneficiaries' best interests, it is arguable that the Crown is required to take action on climate change, through mitigation and/or adaptation, to preserve the culture, well-being and life of Canada's Inuit.

This article begins with an overview of climate justice and its relevance to the Inuit. It explains how litigation in international law and the tort of public nuisance have so far been incapable of providing redress for climate change. It then outlines the history of the Crown's fiduciary obligation toward Canada's Aboriginals, and examines whether existing principles could be extended to recognize an obligation to protect the Inuit from the harmful effects of climate change. It concludes by suggesting the types of action that this obligation might entail. Given Canada's limited ability to reduce worldwide climate change, it seems that the Crown's obligations will most likely be focused on assisting the Inuit to adapt to their changing environment.

This article aims to provide an alternative conceptual framework for legal claims involving arctic climate change; it does not purport to address the finer details of how the litigation would play out. While the judicial application of fiduciary principles to climate justice in the arctic is far from certain, it may provide a source of government obligations that is better established in the jurisprudence and easier to implement than some obligations in international law.

\section{BACKGROUND: CLIMATE JUSTICE AND CANADA'S INUIT}

\section{A. The Unique Position of the Inuit}

The Inuit are in a unique position to make claims for climate justice because global warming is occurring at a faster rate in the arctic than elsewhere. The Arctic Climate Impact Assessment ${ }^{11}$ reported that average temperatures in the arctic have increased at twice the rate as the rest of the world (3-4 degrees Celsius in Alaska and Western Canada over the past half century). ${ }^{12}$ Sea ice, a crucial climate change indicator, has been shrinking at an accelerated pace. ${ }^{13}$ This has had detrimental effects on large mammals, such as polar bears, which depend on the ice for sealhunting and travel. ${ }^{14}$ Seals, birds and walrus are also threatened by the loss of sea ice, which is important for resting, foraging, and raising young. ${ }^{15}$ These declines in marine wildlife are, in turn, detrimental to the Inuit communities who depend on

11 Susan Joy Hassol, Arctic Climate Impact Assessment: Impacts of a Warming Arctic (Cambridge UK: Cambridge University Press, 2004).

12 Ibid at 8,12. This is because the darker surfaces of the Arctic absorb more of the sun's energy, and because a greater concentration of greenhouse gases is directed at warming the atmosphere (as opposed to evaporation, as occurs in the tropics). Ibid at 20.

13 Ibid at 24. The average extent of sea ice has decreased by about $8 \%$, or one million square kilometres, over the past 30 years (at 25).

$14 \mathrm{Ibid}$ at 57 . The shorter season of sea ice means that polar bears have to fast for longer periods of time, which leads, among other things, to reproductive difficulties.

15 Ibid at 59 
them for subsistence. ${ }^{16}$ Similarly, changes in vegetation affect the viability of land mammals, such as caribou, which have particular cultural significance for the Inuit and are an important source of food, clothing and tools. ${ }^{17}$

The Impact Assessment summarized how these changes are threatening vital aspects of Inuit culture:

The living resources of the Arctic not only sustain Indigenous Peoples in an economic and nutritional sense, but also provide a fundamental basis for social identity, spiritual life, and cultural survival. Rich mythologies, vivid oral histories, festivals and animal ceremonies illustrate the social, economic, and spiritual relationships that Indigenous Peoples have with the Arctic environment. These traditions distinguish the food harvesting practices of Indigenous Peoples from conventional hunting. ${ }^{18}$

The impact of climate change on the ringed seal and polar bear populations is particularly dire for the Inuit. As the Impact Assessment explains, "To hunt, catch, and share these foods is the essence of Inuit culture. Thus, a decline in ringed seals and polar bears threatens not only the dietary requirements of the Inuit, but also their very way of life." sea ice over the next century, ringed seals and polar bears are unlikely to survive, and the impact on Inuit communities would be "enormous."

As discussed below, these cultural impacts are crucial if the Inuit are to succeed in a claim for public nuisance. This cause of action would require them to prove that they have sustained damages that are different in kind from those suffered by the general public as a result of global warming. Similarly, the risks to Inuit culture are an important aspect of the claim that the federal Crown has a fiduciary obligation to take some action in response to climate change.

The human rights implications of climate change were recently reviewed in the Report of the Office of the United Nations High Commissioner for Human Rights on the relationship between climate change and human rights. ${ }^{20}$ The report explained how climate change could negatively affect basic human rights like the right to life, food, water, and housing. ${ }^{21}$ It also emphasized the particular vulnerability of Inuit communities, who risk being relocated and whose traditional livelihoods are threatened by climate change. ${ }^{22}$ Because their cultural identity is closely tied to the land, climate change will affect "their collective human rights

16 Ibid at 61. Further, as the geographic range of those species expands, hunters must travel further afield in what are becoming increasingly dangerous and unpredictable conditions.

17 Ibid at 68-71.

18 Ibid at 94.

19 Ibid. A shift to a more Western diet would also increase the risk of cancer, obesity, diabetes and cardiovascular disease. Ibid at 110.

20 UNGA, Human Rights Council, Tenth Session, UN Doc A/HRC/10/61 (15 January 2009) [UNHC Report]. See also John H Knox, "Linking Human Rights and Climate Change at the United Nations" (2009) 33 Harv Envtl L Rev 477.

21 For a detailed discussion of the effects of climate change on both traditional and modern Inuit housing, see Jessie Hohmann, "Igloo as Icon: A Human Rights Approach to Climate Change for the Inuit?” (2009) 18 Transnat'l L \& Contemp Probs 295.

22 UNHC Report, supra note 20 at para 51. 
and their rights as distinct peoples." ${ }^{23}$ The report indicated that climate change may also jeopardize the right to self-determination, including "the right of a people not to be deprived of its own means of subsistence, ${ }^{24}$ and stressed that States have an obligation to involve affected groups in policy-making. ${ }^{25}$ In this vein, indigenous peoples have emphasized the potential contribution of their traditional knowledge in developing "adaptation strategies that are cost-effective, participatory and sustainable. ${ }^{26}$ As will be discussed, the need for consultation with and the participation of Inuit people in measures addressing climate change complements the principles of consultation and accommodation that govern the honour of the Crown and its fiduciary duties toward Aboriginals.

Another important source of obligations toward the Inuit is the United Nations Declaration on the Rights of Indigenous Peoples, ${ }^{27}$ which received the official support of the Canadian government in November $2010{ }^{28}$ Among the principles that are potentially relevant to climate justice are the right to participate in decision-making (article 18), the obligation of States to consult and cooperate in good faith with indigenous peoples (article 19), and the right to just and fair redress where indigenous people are deprived of their means of subsistence (article 20). The Declaration also affirms the right of indigenous peoples to their traditionally owned and occupied lands, and requires States to legally recognize and protect that right (article 26); however, the Canadian government has expressly noted its "concerns" with those provisions. ${ }^{29}$

Particularly important is article 25 of the Declaration, which states that "Indigenous people have the right to maintain and strengthen their distinctive spiritual relationship with their traditionally owned or otherwise occupied and used lands, territories, waters and coastal seas and other resources and to uphold their responsibilities to future generations in this regard." In the context of the Inuit and climate change, this article recognizes that traditional lands and waters are an inherent aspect of indigenous culture and there is an underlying responsibility to preserve this culture for future generations. It also overlaps with the mandate to protect culture that is implicated by the Crown's fiduciary duty toward Aboriginal people, as discussed below. Climate change threatens the traditional territories of the Inuit and, with those territories, the ability of the Inuit

Ibid at para 52.
Ibid at para 39.
Ibid at para 79.
Ibid at para 52, quoting the Permanent Forum for Indigenous Issues, E/C.19/2008/13 at para 4.
GA 61/295, UNGAOR, 107th plenary meeting (13 September 2007). See also Organization of

American States, Human Rights and Climate Change in the Americas (AG/RES 2429, adopted 3 June 2008), which resolved to explore the "possible links between climate change and human rights."

28 Canada's Statement of Support on the United Nations Declaration on the Rights of Indigenous Peoples (12 November 2010). The Statement described the Declaration as an "aspirational" document, and indicated that Canada had ongoing concerns about the Declaration's provisions dealing with, inter alia, lands, territories and resources.

29 Ibid. In addition, article 28 provides that indigenous people have the right to compensation when their traditional lands, territories and resources are taken or damaged without their consent. This compensation can take the form of other lands, monetary compensation or "other appropriate redress." 
to engage in traditional spiritual and subsistence practices both now and in the future.

\section{B. Progress to Date}

Despite being a relatively sympathetic class of plaintiffs, the Inuit have so far had disappointing results in their attempts to obtain redress for climate change through international law and the common law of torts. These failures highlight the difficulties posed by rules of standing and justiciability, and the weak enforcement mechanisms available at international law. Moreover, both scholars and courts have pointed out the difficult issues of causation, fault and remedies that arise when climate change actions are framed as public nuisance. ${ }^{30}$ Although common law and international remedies have not been exhausted, the difficulties experienced so far suggest that a new paradigm may be necessary if climate justice is to be obtained for Canada's Inuit.

\section{Claims in Common Law Public Nuisance}

The Kivalina case, introduced above, is exemplary of the problems faced by plaintiffs claiming damages at common law for the negative effects of climate change. The plaintiff is a Native Village in Alaska whose coast has historically been protected by sea ice. Due to global warming, the sea ice now freezes later in the year and breaks up earlier, which ultimately subjects Kivalina to coastal storm waves and surges. This has, in turn, caused erosion of the coast, which is rendering the Village uninhabitable. The plaintiff therefore brought a federal public nuisance claim against some two dozen oil, energy and utility companies, whose allegedly excessive emission of greenhouse gases contributed to global warming. The Village claimed that it will have to relocate, at a cost estimated from $\$ 95$ to $\$ 400$ million.

The District Court granted the defendants' motion to dismiss the claim for lack of subject matter jurisdiction on two different bases. First, the dispute was barred by the "political question doctrine," which is invoked when a claim raises questions that ought to be decided by the political branches of government, rather than the judiciary. ${ }^{31}$ In particular, the case raised issues that were beyond the scope of judicial expertise, such as the viability of alternative energy sources and their relative economic and environmental benefits and drawbacks. In the court's view, the claim in Kivalina was distinguishable from other environmental nuisance cases, which typically involve a small number of defendants emitting a specific pollutant in a well-defined area. Climate change, in contrast, is caused by a multitude of actors around the world, over an extended period of time, affecting the entire planet. ${ }^{32}$ Further, deciding a climate change nuisance case would require

30 Claims for environmental harm, by the Inuit and others, have typically been framed in terms of nuisance (private or public) rather than the tort of negligence. This preference has a long pedigree: see J Morris, "Climbing Out of the Hole: Sunsets, Subjective Value, the Environment, and the English Common Law” (2002) 14 Fordham Envtl LJ 343. Negligence claims would, among other difficulties, suffer from similar problems of causation as public or private nuisance claims.

31 See Baker v Carr, 369 US 186 (1962), which sets out the factors that identify a dispute as a nonjusticiable political question. See also Boomer v Atlantic Cement, 26 NY.2d 219 (1970) at 223 (Bergan J), where the court stressed that matters of public interest, like air pollution, could not be solved as a "by-product" of resolving private disputes.

32 Kivalina, supra note 6 at 875. 
the court to make policy decisions about what levels of greenhouse gas emissions would be appropriate, and who should bear the cost of global warming.

The court's second basis for dismissing the claim was the lack of standing; specifically, that the plaintiff's injury was not "fairly traceable" to the defendant's conduct. ${ }^{33}$ This variation on the causation requirement was unsatisfied for reasons similar to those just outlined: global warming dates back centuries and is attributable to "a multitude of sources other than the defendants." ${ }^{34}$ It is the result of many greenhouse gases accumulating in the atmosphere over time. Accordingly, it cannot be pinned on the particular defendants named in the action. The court also commented on what it considered a weak chain of causation: "emitted greenhouse gases combine with other gases in the atmosphere which in turn results in the planet retaining heat, which in turn causes the ice caps to melt and the oceans to rise, which in turn causes the Arctic sea ice to melt, which in turn allegedly renders Kivalina vulnerable to erosion and deterioration resulting from winter storms." ${ }^{35}$ Accordingly, the court granted the defendants' motion for summary dismissal of the case.

Although based on standing and jurisdictional rules in the federal courts of the United States, the decision in Kivalina illustrates the problems that would arise if a similar common law public nuisance claim were brought in Canada. The American political question doctrine has its parallel in the Canadian principle of justiciability, which arises in both tort $^{37}$ and administrative law. ${ }^{38}$ In the climate change context, the issue of justiciability arose in Friends of the Earth $v$ Canada (Governor in Council), ${ }^{39}$ a 2008 decision of the Federal Court. The plaintiff notfor-profit environmental organization brought three applications for judicial review of the government's compliance with the Kyoto Protocol Implementation Act. ${ }^{40}$ The Act was initiated as a private member's bill, and was aimed at ensuring that the federal government implemented its commitments under the Kyoto Protocol. $^{41}$ Among other things, the Act required the government to submit an annual Climate Change Plan describing the measures taken to ensure that Canada meets its Kyoto obligations. The government's initial Climate Change Plan, released in August 2007, indicated that Canada would not meet its obligations

\section{Ibid at 877.}

Ibid at 880 .

Ibid at 876 (Emphasis in original).

36 The decision was affirmed by the 9th Circuit Court of Appeals (696 F.3d 849 (2012)) on the basis of the preemption doctrine set out by the Supreme Court in AEP v Connecticut, supra note 9 (discussed below).

37 See Black v Chretien (2001), 199 DLR (4th) 228 (Ont CA), where it was found that the Prime Minister's decisions regarding the conferral of honours were non-justiciable. A similar issue arises with respect to so-called "policy" decisions in the law of negligence. See especially Just v British Columbia (Minister of Transportation and Highways), [1989] 2 SCR 1228; Cooper v Hobart, [2001] 3 SCR 537; L (A) v Ontario (Minister of Community \& Social Services) (2006), 83 OR (3d) 512 (CA).

38 See generally Lorne M Sossin, Boundaries of Judicial Review: The Law of Justiciability in Canada (Scarborough: Carswell, 1999).

39 [2009] 3 FCR $201[$ FoE $]$.

40 SC 2007, c 30.

41 Kyoto Protocol to the United Nations Framework Convention on Climate Change, 11 December 1997, 2303 UNTS 148 (in force 2005). 
under the Kyoto Protocol, claiming that compliance would force Canada into a "deep recession." ${ }^{42}$ The plaintiff sought judicial review of the government's submission of a Climate Change Plan that was non-compliant with Canada's Kyoto obligations.

As with the political question doctrine applied in Kivalina, Barnes $\mathrm{J}$ stated that the purpose of the doctrine of justiciability is to respect the separation of powers between branches of government. ${ }^{43}$ Barnes J summarized: "Generally a court will not involve itself in the review of the actions or decisions of the executive or legislative branches where the subject matter of the dispute is either inappropriate for judicial involvement or where the court lacks the capacity to properly resolved [sic] it." ${ }^{44}$ Applying this principle, Barnes $\mathrm{J}$ found that ensuring compliance with the Kyoto Protocol involved "policy-laden considerations" that would affect various aspects of the economy, and that there were no objective criteria by which a court could decide whether compliance with the legislation had been achieved. ${ }^{45}$ In addition, the Act's reference to constantly-changing scientific and political environments, and the need to work with third parties (eg provincial authorities and industry) suggests that Parliament contemplated the possibility that strict compliance with the Kyoto Protocol may not be achievable in a given timeframe. Accordingly, Parliament could not have intended for the Act to create justiciable duties. ${ }^{46}$ Barnes $\mathrm{J}$ concluded by suggesting that compliance with the Kyoto Protocol was a matter of the Minister of the Environment's accountability to Parliament, the scientific community and the general public, but was not properly suited to judicial scrutiny. ${ }^{47}$ Although Friends of the Earth was a claim for judicial review, similar questions of justiciability would likely arise in a Canadian claim for the tort of public nuisance.

Even if a plaintiff were to overcome the question of justiciability, a public nuisance claim for climate change brought in Canada would most likely suffer from the same difficulties in proving causation as the claim in Kivalina. Canadian plaintiffs would have particular difficulties proving causation because of the apparent requirement in public nuisance that the plaintiff's damage be "direct and not consequential." Given the chain of events that leads from the emission of

42 Climate Change Plan (Ottawa: Minister of the Environment, 2007) at 8, quoted at para 12 of FoE, supra note 39.

$43 \quad$ FoE , ibid at para 25.

44 Ibid.

45 Barnes J cited, for e.g., section 5(1)(d) of the Kyoto Protocol Implementation Act, which requires an equitable distribution of reduction levels among those sectors of the economy that contribute to greenhouse gas emissions. Ibid at para 33 .

$46 \quad$ Ibid at para 35.

$47 \quad$ Ibid at paras $42-43$.

48 See e.g., Palmer v Nova Scotia Forest Industries (1983), 60 NSR (2d) 271 (SC (TD)), in which the plaintiffs sought an injunction prohibiting the defendant from spraying of phenoxy herbicides in given areas and a declaration that they had a right to be free from exposure to such herbicides. Nunn $\mathrm{J}$ found the declaration sought by the plaintiffs to be non-justiciable, and was more suitable to resolution by the government or a regulatory agency, rather than the court.

49 Hickey $v$ Electric Reduction Co of Canada (1970), 21 DLR (3d) 368 (Nfld SC) at 372. In that case, the defendant had discharged waste from its plant at Long Harbour, which destroyed the local fish population. The plaintiff fishermen brought an unsuccessful action in public nuisance for their loss of livelihood. Furlong CJ rejected their claim on the ground that their injuries were not different in kind or degree from those of the general public (who were similarly unable to 
greenhouse gases to the eventual harms to life, health and culture suffered by Canada's Inuit, it would be exceedingly difficult to prove that the plaintiff's injuries were the "direct" result of the defendant's actions. Combined with the fact that climate change is the result of emissions by millions of polluters over centuries, the plaintiffs' claims for public nuisance would not be promising.

\section{Common Law Claims for Damage to Culture}

While it was not a climate change case, In re Exxon Valdez ${ }^{50}$ also yielded disappointing results for the Inuit. As one of the multitude of actions brought after the Exxon Valdez ran aground in Prince William Sound in 1989, Native peoples in Alaska brought a public nuisance claim alleging that the devastation of fish stocks and coastlines was harmful to their subsistence way of life. They claimed that their lifestyle was "dependent upon the preservation of uncontaminated natural resources, marine life and wildlife, and reflects a personal, economic, psychological, social cultural, communal and religious form of daily living." They also alleged harm to their archaeological sites and artifacts. However, the court granted summary judgment against the plaintiffs, claiming that their alleged injuries were not different in kind from those suffered by other Alaskans, as would be required for a successful claim in public nuisance. The Ninth Circuit Court of Appeals affirmed the District Court Judge's decision that the right to obtain food, cultural and psychological benefits from the natural surroundings was shared by all Alaskans. The court thereby rejected the plaintiffs' arguments that they had suffered special damage.

In re Exxon Valdez is a particularly disheartening rejection of the Inuit's claim to cultural damages in the common law of public nuisance. It seems to deny out of hand that there is anything special about the Inuit's relationship to the natural environment, and strikes a blow against the principles of environmental and climate justice. As one author has critiqued, the decision in In re Exxon Valdez. ignores the special nature of subsistence to indigenous peoples: "Damage to the resources supporting a subsistence way of life can be more harmful to Alaska Natives than to someone else who theoretically depends on the resources to a quantitatively equal degree because of its impact on their spiritual and community life. Furthermore, many Alaska Natives' identities as members of a native group are bound up in their practice of subsistence living.",52

Nevertheless, as discussed in section III(e), there is reason to be more optimistic about claims for cultural damages in Canada. The Canadian courts have been more sensitive to arguments about the importance of the cultural traditions of Aboriginal peoples, including those that are tied to the land. In addition, the honour of the Crown and its fiduciary obligations toward Aboriginals include a requirement to respect and preserve their cultural heritage. Thus, threats to Inuit culture and traditional lifestyle would be important considerations in any assessment of the Crown's obligation to address climate change.

fish). Furlong CJ also indicated that a successful action would require a direct injury, and suggested that "it would be a matter of extreme difficulty" to say what direct damages the plaintiffs suffered in the case.

$51 \quad$ Ibid at 1197.

52 DS Bardwick, "The American Tort System's Response to Environmental Disaster: The Exxon Valdez Oil Spill as a Case Study" (2000) 19 Stan Envtl LJ 259 at 280-81. 


\section{Claims in International Law}

The Inuit have also sought relief for climate change in international law. In December 2005, the Inuit Circumpolar Conference submitted a petition before the Inter-American Commission on Human Rights seeking relief from the United States for the rights-violations caused by global warming. ${ }^{53}$ The petition was brought on behalf of the Inuit in the Canadian and American arctic. It set out the effects of global warming on the arctic region, including changes in sea ice, snowfall and permafrost. It also explained the particular impact of global warming on indigenous peoples, who "are a product of the physical environment in which they live. ${ }^{54}$ For instance, the loss of sea ice has made travel difficult and dangerous, which curtails hunting activities and reduces the opportunity for communication between communities. Changes in the quantity and quality of snow have made it difficult to build igloos, thus leaving travelers with inadequate shelter and threatening an important component of Inuit culture. ${ }^{55}$ In addition, climate change has had a negative impact on arctic wildlife, which are an essential food source for the Inuit. Finally, as indicated in the Kivalina litigation, erosion of shorelines may force some communities to relocate altogether.

The petition alleged that the United States, as a leading producer of the greenhouse gases that cause climate change, has violated various international agreements, particularly the American Declaration of the Rights and Duties of Man. Most notably, the Inuit's right to life and health are violated because of forced changes to their diet, threats to natural sources of drinking water, and an increase in sun or heat-related illnesses. ${ }^{56}$ Their right to their own means of subsistence has been violated due to the decline in wildlife and the travelling difficulties of hunters. Stemming from these violations, the Inuit's right to culture has also been dishonoured. As the Petition explains, "Because Inuit culture is inseparable from the condition of their physical surroundings, the widespread environmental upheaval resulting from climate change violates the Inuit's right to practice and enjoy the benefits of their culture. The subsistence culture central to Inuit cultural identity has been damaged by climate change...., ${ }^{57}$

The petition claimed that the United States was implicated in these violations as the largest contributor to greenhouse gases worldwide. Although the American government acknowledges human responsibility for climate change, and has ratified the UN Framework Convention on Climate Change, it has rejected international efforts to reduce greenhouse gas emissions, in particular the Kyoto Protocol. The petition ultimately requested that the United States take "immediate and effective action to protect the rights of the Inuit.. ${ }^{58}$

The Inuit Circumpolar Petition was not the first instance of an indigenous group seeking redress under the American Declaration for environmental harm. In Saramaka People v Suriname, ${ }^{59}$ the petitioners sought reparations for violations of

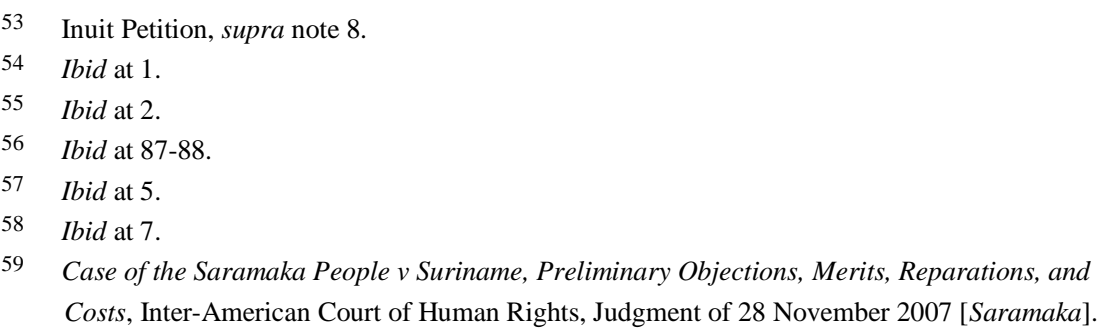


their collective property rights due to logging and mining that occurred on their traditional territories without their consent. Of particular relevance to the Inuit, the Saramaka people rested much of their claim on their traditional spiritual connection with the land. The Inter-American Court of Human Rights affirmed that the Saramaka people had a "right to the communal territory they have traditionally used and occupied, derived from their longstanding use and occupation of the land and resources necessary for their physical and cultural survival, and that the State has an obligation to adopt special measures to recognize, respect, protect and guarantee the communal property right of the members of the Saramaka community to said territory." reaffirmed the "special relationship" that indigenous groups have with their territory and its necessity for their physical and cultural survival. ${ }^{61}$ Citing its own jurisprudence, the court explained:

the close ties of indigenous people with the land must be recognized and understood as the fundamental basis of their cultures, their spiritual life, their integrity, and their economic survival. For indigenous communities, [their relationship with] the land is not merely a matter of possession and production but a material and spiritual element, which they must fully enjoy [...] to preserve their cultural legacy and transmit to future generations.

Having found that the petitioners' communal property rights were violated, the Court awarded not only material damages, but also immaterial damages to recognize how environmental damage had affected "the spiritual connection the Saramaka people have with their territory" as well as the suffering and distress they endured in their fight to achieve legal recognition of their territorial rights. ${ }^{6}$ The court accordingly awarded $\$ 600,000$ (US) to establish a community development fund for the benefit of the Saramaka people, to assist with education, housing and health projects, electricity and drinking water. ${ }^{64}$ The decision in the Saramaka case thus provided apparent authority for the recognition of claims by indigenous people for environmental damage, including the cultural harm that this entails.

Unfortunately, the Inuit Circumpolar Petition was not as well-received. Although the petition ran to 167 pages of supporting evidence, the Inter-American Commission responded by indicating that "the information provided does not enable us to determine whether the alleged facts would tend to characterize a violation of rights protected by the American Declaration." ${ }^{65}$ The Commission held a related hearing on climate change and human rights in March 2007, but has done nothing since. This response to the petition was undoubtedly disappointing. But

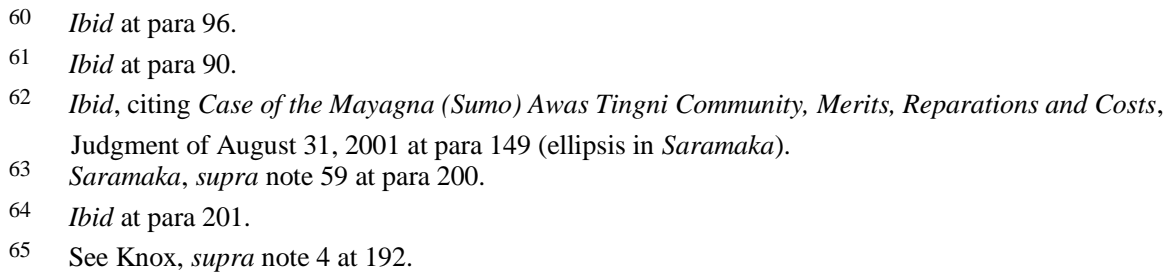


even if the Commission had found the Petition to be admissible, its ability to enforce an effective remedy would be weak. ${ }^{66}$ Indeed, the remedies sought by the petitioners were largely framed in terms of recommendations that the United States take steps to limit its greenhouse gas emissions, consult with the Inuit in preparing plans to protect their environment, and assist them in adapting to the effects of climate change.

The lead petitioner and Chair of the Inuit Circumpolar Conference, Sheila Watt-Cloutier, has acknowledged that the petition was unlikely to lead to legally enforceable remedies. At the 2005 Conference of Parties of the United Nations Framework Convention on Climate Change, Watt-Cloutier stated: "A declaration from the commission may not [be] enforceable, but it has great moral value. We intend the petition to educate and encourage the United States to join the community of nations in a global effort to combat climate change.... This petition is our means of inviting the United States to talk with us and to put this global issue into a broader human and human rights context." ${ }^{67}$ She thus recognized that international legal mechanisms will be more helpful as political tools than as enforceable remedies in the climate justice movement.

Even apart from the Inuit Circumpolar Petition, the ability of international law to address the cultural impact of climate change on the Inuit is limited. Under the International Covenant on Civil and Political Rights, ${ }^{68}$ for example, indigenous peoples have not generally been assigned the status of "peoples" (who have a right of self-determination and who "in no case may... be deprived of [their] own means of subsistence"), ${ }^{69}$ but rather, have been classified as ethnic minorities under Article 27. Although Article 27 prohibits States from denying minorities the ability to enjoy their own culture, it does not provide an affirmative obligation to protect that culture. $^{70}$ Accordingly, the Inuit will most likely need to look elsewhere if they wish to seek legal relief for the physical and cultural effects of climate change.

\section{The US Supreme Court's Decision in $A E P$}

Finally, the entire field of climate change litigation suffered a serious setback after the United States Supreme Court's decision in AEP v Connecticut. ${ }^{71}$ That case involved a claim in federal common law nuisance by the city of New York, several states and three non-profit private land trusts against five large carbon dioxide emitters (four private power companies and the Tennessee Valley Authority). The claim alleged that the defendants' carbon dioxide emissions created an interference

66 See generally Hari M Osofsky, "The Inuit Petition as a Bridge? Beyond Dialectics of Climate Change and Indigenous Peoples' Rights” (2007) 31 Am Indian L Rev 675.

67 Sheila Watt-Cloutier, "The Climate Change Petition by the Inuit Circumpolar Conference to the Inter-American Commission on Human Rights" presented to Eleventh Conference of Parties to the UN Framework Convention on Climate Change (Montreal, 7 December 2005), online: <http://www. inuitcircumpolar.com/index.php?I-D=318\&Lang=En>.

6819 December 1966, 999 UNTS 171 (entered into force 23 March 1976, accession by Canada 19 May 1976) [ICCPR].

69 Ibid, Art 1.

70 See Tsosie, supra note 1 at 1664-65. See also RA Williams, Jr, "Encounters on the Frontiers of International Human Rights Law: Redefining the Terms of Indigenous Peoples' Survival in the World" (1990) 4 Duke LJ 660.

71 Supra note 9. 
with public rights, including risks to health, natural habitats, and wildlife, and sought abatement of this nuisance through reductions in carbon dioxide emissions. In dismissing the claim, the court found that the federal common law was displaced by the Clean Air Act and its delegation of authority over air pollution to the Environmental Protection Agency (EPA). The Act provides for both the establishment of pollution standards and their enforcement, and displaces the federal common law even though the EPA has yet to regulate carbon dioxide emissions. As Ginsburg J wrote, "were the EPA to decline to regulate carbondioxide emissions altogether... the federal courts would have no warrant to employ the federal common law of nuisance to upset the agency's expert determination." ${ }^{72}$

The decision in $A E P$ thus favoured a regulatory approach over tort law as a means of addressing climate change. This is not altogether a bad thing, as it allows for judicial review of government action (or inaction) taken pursuant to various environmental statutes, a field of litigation that seems relatively robust in the United States. ${ }^{73}$ However, by foreclosing federal common law nuisance claims, the $A E P$ decision has deprived potential claimants of an important compensatory tool. As Maxine Burkett has explained, the inability to bring tort claims thwarts the goal of corrective justice to repair losses caused by a wrongdoer to a particular victim. ${ }^{74}$ There is an inherently relational aspect to tort law that is absent in the regulatory approach. Burkett suggests that the "rectification of harms suffered can help restore the moral balance upset by the externalized costs that climate change inflicts on individuals and communities. The corollary, therefore, is that tort law should provide a venue and possible damages remedy for [climate justice] plaintiffs whose claims - namely, injuries to life and property - demand compensation from the worst offenders." ${ }^{75}$ Burkett argues that AEP is particularly harmful to the climate justice project because it suggests to the "climate vulnerable" that the law is ineffective and that their concerns will not be heard.

\section{THE CROWN'S FIDUCIARY DUTY TO ABORIGINAL PEOPLES}

The preceding discussion suggests that Canada's Inuit are unlikely to achieve compensation for climate change under the existing law of tort or at international law. Accordingly, it may be useful to explore other theories of responsibility. In particular, it is worthwhile to assess whether the federal Crown's fiduciary obligation toward Aboriginal peoples encompasses an obligation to protect the Inuit from the harmful effects of climate change, or to help them adapt to their changing environment. As outlined below, the Supreme Court of Canada has produced a substantial body of jurisprudence on this sui generis fiduciary obligation over the past three decades. This obligation has typically been applied to Crown actions affecting Aboriginal property rights or the ability to carry out

\footnotetext{
Ibid at 2538-39. However, judicial review of the EPA's decision would be available.

See Hari M Osofsky, "AEP v Connecticut's Implications for the Future of Climate Change

Litigation" (2011) 21 Yale LJ Online 101, online: Yale Law Journal <http://yalelawjournal.org/2011/09/13/osofsky.html>.

74 Maxine Burkett, "Climate Justice and the Elusive Climate Tort" (2011) 121 Yale LJ Online 115,

online: Yale Law Journal <http://yalelawjournal.org/2011/09/13/burkett.html〉.

Ibid.
}

75 
traditional practices. It is arguable that the Crown's fiduciary duty is implicated in the harms caused to Inuit lands and the threats to subsistence culture that are the result of global warming.

The following sections set out the rationales for the Crown's fiduciary obligations to Aboriginals and the scope in which it has traditionally been applied. While protection from the effects of climate change does not fall within the traditional scope of the fiduciary obligation, a sound argument can be made based on the duty's underlying principles. For instance, because fiduciary obligations are often tied to property rights and vulnerability, the close connection between the land and cultural survival for the Inuit may justify invoking fiduciary concepts.

\section{A. Overview of the Crown's Fiduciary Obligation}

The Crown's fiduciary obligation was first established in Guerin $v$ The Queen, ${ }^{76}$ where the plaintiff Indian Band had surrendered a portion of its reserve to the Crown pursuant to the Indian Act..$^{77}$ The statutory scheme, traceable back to the Royal Proclamation of $1763,{ }^{78}$ provided that Aboriginals could not alienate their real property directly to third parties, but first had to surrender it to the Crown. Dickson $\mathrm{J}$, for the majority, explained that this inalienability of the Aboriginal interest in land gives rise to a fiduciary obligation on the Crown "to deal with the land for the benefit of the Indians." ${ }^{, 79}$ He wrote,

The fiduciary relationship between the Crown and the Indians has its roots in the concept of aboriginal, native or Indian title....

An Indian Band is prohibited from directly transferring its interest to a third party. Any sale or lease of land can only be carried out after a surrender has taken place, with the Crown then acting on the Band's behalf. The Crown first took this responsibility upon itself in the Royal Proclamation of $1763 . .$. The surrender requirement, and the responsibility it entails, are the source of a distinct fiduciary obligation owed by the Crown to the Indians.

The purpose of this arrangement was to prevent Aboriginals from being exploited. $^{81}$ Although it did not properly give rise to a trust, it was "trust-like in character." ${ }^{82}$ On the facts of the case, the fiduciary obligation was breached because the Crown had induced the Band to surrender by promising that it would obtain a lease for the land on certain terms, but then negotiated the lease on less favourable terms. The Crown was accordingly liable for the Band's loss.

\footnotetext{
76 [1984] 2 SCR 335 [Guerin].

77 Now RSC 1985, c I-5, s 18(1).

78 RSC 1985, App II, No 1.

79 Guerin, supra note 76 at 376.

80 Ibid.

$81 \quad$ Ibid at 383

82 Ibid at 386

83 The court upheld the trial judge's global damages assessment of $\$ 10$ million. See also Blueberry River Indian Band v Canada, [1995] 4 SCR 344, where the court found that the Crown had
} 
Following the decision in Guerin, the Crown's fiduciary obligation toward Aboriginals was affirmed in various contexts, including treaty interpretation ${ }^{84}$ and the creation of reserves. ${ }^{85}$ In $R v$ Sparrow, ${ }^{86}$ the Crown's fiduciary obligations were expressly tied to section 35(1) of the Constitution Act, 1982, which states: "The existing aboriginal and treaty rights of the aboriginal peoples of Canada are hereby recognized and affirmed." $"$ The issue in that case was whether a statutory net length restriction on a Band's food fishing licence was inconsistent with the exercise of Sparrow's Aboriginal right to fish under section 35(1). The court reviewed earlier cases and determined that the general guiding principle is that "the Government has the responsibility to act in a fiduciary capacity with respect to aboriginal peoples. The relationship between the Government and aboriginals is trust-like, rather than adversarial, and contemporary recognition and affirmation of aboriginal rights must be defined in light of this historic relationship." In terms of the rights under section 35(1), the Crown's fiduciary obligation meant that there was "some restraint on the exercise of sovereign power," for example, to regulate fisheries. ${ }^{88}$ Accordingly, any encroachment on the Aboriginal right to fish had to be justified by a valid legislative objective, pursued in a manner that upholds the "honour of the Crown." The court explained, "The special trust relationship and the responsibility of the government vis-à-vis aboriginals must be the first consideration in determining whether the legislation or action in question can be justified." 90

The two strands of cases following Guerin and Sparrow indicate that the Crown's fiduciary duty is implicated in dealings involving both Aboriginal title to land and the practice of Aboriginal rights. ${ }^{91}$ However, the nature of the fiduciary obligation was often discussed in broad, overarching terms, and the precise scope and terms of the obligation were not set out. ${ }^{92}$ This created a tendency to characterize the Crown-Aboriginal fiduciary relationship as all-encompassing - a tendency that was identified and seriously curtailed in Wewaykum Indian Band $v$ Canada.

breached its fiduciary duty to the plaintiff by failing to reserve mineral rights when it sold the land that the Band had surrendered.

$R v$ Badger, [1996] 1 SCR 771.

Ross River Dena Council Band v Canada, [2002] 2 SCR 816 at para 68 (LeBel J).

[1990] 1 SCR 1075 [Sparrow].

Constitution Act, 1982, being Schedule B to the Canada Act 1982 (UK), 1982, c 11, s 35(1).

Sparrow, supra note 86 at 1108.

89 Ibid at 1109. The court went on to explain the process of such justification, noting that conservation and resource management were a legitimate government objective.

Ibid at 1114. The case was returned to the lower courts for a new trial as to whether the net length restriction infringed Sparrow's right to fish, and if so, whether this infringement was justified.

91 For discussion of the differences between these two categories of fiduciary obligations, see David W Elliott, "Much Ado about Dittos: Wewaykum and the Fiduciary Obligation of the Crown" (2003) 29 Queen's LJ 1.

92 For more detailed criticism of this tendency to portray the fiduciary obligation of the Crown as self-evident (and therefore not in need of analysis), see Leonard Rotman, Parallel Paths: Fiduciary Doctrine and the Crown-Native Relationship in Canada (Toronto: University of Toronto Press, 1996) at 11-16 [Parallel Paths]. 
Wewaykum involved competing claims to two reserves by two Indian Bands in British Columbia, stemming back to the original allocation of reserves on the province's entry into Confederation. Owing to ongoing federal/provincial political tensions and certain clerical inconsistencies, it was not clear which reserve had been allocated to which Band. Indeed, both Bands claimed ownership of both reserves, arguing that the other Band had no interest at all. But since it would be a hardship, after so many years, to displace the other Band, they claimed equitable compensation from the Crown instead. The Supreme Court of Canada unanimously dismissed these claims, agreeing with the trial judge's conclusion that there had been no wrongdoing by the federal Crown, and that the claims were barred by the limitations period and laches in any event. However, Wewaykum is more important for its rejection of the notion that the Crown's fiduciary duty was "a source of plenary Crown liability covering all aspects of the Crown-Indian band relationship." ${ }^{94}$ Binnie J continued: "This overshoots the mark. The fiduciary duty imposed on the Crown does not exist at large but in relation to specific Indian interests." ${ }^{, 5}$

The court explained that, as with all fiduciary relationships, not every obligation owed by a fiduciary is itself a fiduciary duty: "It is necessary, then, to focus on the particular obligation or interest that is the subject matter of the particular dispute and whether or not the Crown had assumed discretionary control in relation thereto sufficient to ground a fiduciary obligation. ${ }^{.96}$ In order to invoke a fiduciary obligation in a particular case, the claimant would need to identify a "cognizable Indian interest, and the Crown's undertaking of discretionary control in relation thereto. ${ }^{.97}$ Further, the content of the fiduciary duty would vary "with the nature and importance of the interest sought to be protected." ${ }^{98}$ For example, different fiduciary duties arise with respect to reserve creation, reserve protection, and reserve disposition.

The effect of Wewaykum is to preclude the imposition of liability based on vague or overarching assertions that the Crown owed and breached a fiduciary obligation. The decision brings the Crown's fiduciary obligation toward Aboriginal peoples, which has always been characterized as sui generis, closer in line with general principles of fiduciary duty in Canada. Claimants will need to establish a cognizable interest over which the Crown has undertaken discretionary control. This is consistent with more general jurisprudence on the nature of fiduciary relationships, which are typically characterized by the vulnerability of one party to the discretion of another, particularly when the fiduciary has assumed or been given the authority to make decisions that affect the important interests of the principal/beneficiary. ${ }^{99}$ It is largely this power imbalance that grounds the fiduciary obligation to act with good faith and loyalty and in the best interests of the more vulnerable party.

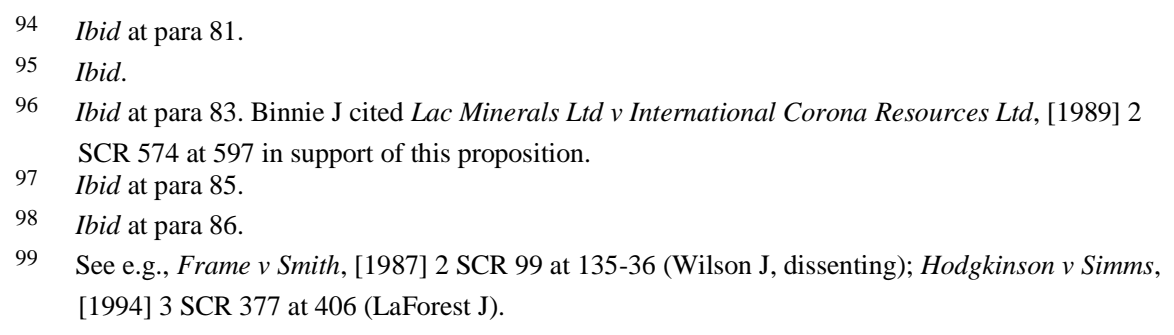




\section{B. Rationales for the Crown's Fiduciary Obligation}

Since the recognition of the Crown's fiduciary obligations toward Aboriginals in Guerin, courts and commentators have suggested several underlying bases for the obligation. It is not the purpose of this article to promote any particular theory of the Crown's fiduciary obligation. Instead, it sets out the various theories in an attempt to determine how best to characterize the Crown's obligations to the Inuit with respect to climate change.

In an early article, ${ }^{100}$ Brian Slattery suggested that the Crown's fiduciary duties toward Aboriginals are rooted "in the Crown's historical commitment to protect native peoples from the inroads of British settlers, in return for a native undertaking to renounce the use of force to defend themselves and to accept instead the protection of the Crown as its subjects." ${ }^{101}$ Slattery thus viewed the fiduciary obligation as politically expedient: it was necessary to form a peaceful alliance with Aboriginals, who held considerable military and economic capacities at the time. Underlying Slattery's view is an assumption that Aboriginals "traded" or forfeited their sovereignty in exchange for Crown protection.

Leonard Rotman has provided a more one-sided interpretation of the roots of the Crown's fiduciary obligation. In his view, sovereignty was not voluntarily traded by Aboriginals; rather, after defeating the French, the British Crown assumed control over native lands as part of its colonial enterprise. ${ }^{102}$ This assumption was evident in the Royal Proclamation, 1763 and in the various documents by which the provinces joined Confederation. ${ }^{103}$ For instance, section 92(24) of The Constitution Act, 1867 gave the federal government authority over "Indians, and Lands reserved for the Indians." "104 In Ontario Mining Company $v$ Seybold, ${ }^{105}$ this section was explained by Gwynne $\mathrm{J}$ of the Supreme Court of Canada:

[The lands in question] should be regarded, as all lands in like circumstances have always been regarded ever since the proclamation of 1763, namely as lands vested in Her Majesty in trust for the sole use and benefit of the Indians upon the terms and conditions agreed upon as those upon which the trust was accepted by Her Majesty; and, as I have already said it was, in my opinion, for the purpose of maintaining unimpaired a continuance of that condition of things that the subject "Indians and lands reserved for the Indians" was placed under the exclusive legislative authority of the Dominion Parliament. ${ }^{106}$

Rotman shows that the early legislative and judicial record treated native lands as being held on trust by the federal Crown for the use and benefit of Aboriginals. He

100 Brian Slattery, “Understanding Aboriginal Rights” (1987) 66 Can Bar Rev 727.

101 Ibid at 753.

102 Rotman, Parallel Paths, supra note 92, ch 3.

103 Ibid, ch 4.

$10430 \& 31$ Vict, c 3, s 92(24).

105 (1901), 32 SCR 1 . The case turned on whether given lands belonged to the federal or provincial government.

$106 \mathrm{Ibid}$ at 14 . Gwynne $\mathrm{J}$ dissented in the result. 
argues that the fiduciary obligation has been assumed and asserted by the Crown from at least as far back as 1763, and is inherent in the federal government's constitutional authority over "Indians." Rotman also traces the jurisprudential history of the Crown's fiduciary obligation to cases like St Ann's Shooting and Fishing Club v The King, ${ }^{107}$ where Rand J referred to Aboriginals as "wards of the state, whose care and welfare are a political trust of the highest obligation." Thus, he shows that the decision in Guerin, while an apparent watershed in modern jurisprudence, is of a lengthy historical pedigree.

Evan Fox-Decent builds on Rotman's thesis but takes a less benevolent reading of both the historical record and the modern recognition of the Crown's fiduciary duty. Fox-Decent argues that the courts have recognized the Crown's fiduciary obligation ex post facto as a means of legitimizing the Crown's de jure sovereignty over Aboriginals, which was assumed without their consent. ${ }^{108}$ He notes how the courts have, on the one hand, recognized that Canada's Aboriginals had sovereign laws and interests prior to contact with Europeans; on the other, the courts have always taken Crown sovereignty to be "an uncontestable given." "Fox-Decent argues that, in cases like Mitchell $v M N R,{ }^{110}$ the Supreme Court has used the Crown's overarching fiduciary obligation "to take some of the sting and imperiousness out of the Crown's assertion of sovereignty," which effectively extinguished Aboriginal sovereignty. ${ }^{111}$ As McLachlin CJC wrote in Mitchell, "With this assertion [of Crown sovereignty] arose an obligation to treat aboriginal peoples fairly and honourably, and to protect them from exploitation, a duty characterized as "fiduciary' in Guerin v The Queen.",

Fox-Decent reasons that, by characterizing the Crown's relationship to Aboriginals as fiduciary, the courts have precluded the Crown from unilaterally setting the terms for their interaction. This creates "a measure of legitimacy that would be lacking were the Crown able to set the terms of those relations at its sole discretion." ${ }^{113}$ Fox-Decent's view seems to be supported by cases like $R v$ Van der Peet, ${ }^{114}$ where Lamer CJC explained that section 35(1) of the Constitution Act, 1982 was meant to "reconcile" Crown sovereignty with the prior occupation of Canada by its Aboriginal peoples. Although Aboriginals no longer enjoy de jure sovereignty, the constitutional framework prohibits the Crown from taking unjustified actions that infringe on their right to engage in culturally distinctive practices.

\footnotetext{
107 [1950] 2 DLR 225 (SCC) at 232.

108 Evan Fox-Decent, "Fashioning Legal Authority from Power: The Crown-Native Fiduciary Relationship" (2006) 4 NZJPIL 91.

109 Ibid at 109.

110 [2001] 1 SCR 911 [Mitchell].

111 Fox-Decent, supra note 108 at 110.

112 Mitchell, supra note 110 at para 9 (citations omitted). See also L'Heureux-Dubé J (dissenting) in $R v$ Van der Peet, [1996] 2 SCR 507 at para 144: "This fiduciary obligation attaches because of the historic power and responsibility assumed by the Crown over aboriginal people."

113 Fox-Decent, supra note 108 at 111. But see the minority reasons of Binnie J (Major J concurring), which treat Aboriginal sovereignty as "shared" or "merged" with Canadian sovereignty, not subjugated by it. Mitchell, ibid at para 135. See also Michael Coyle, "Loyalty and Distinctiveness: A New Approach to the Crown's Fiduciary Duty Toward Aboriginal Peoples" (2003) 40 Alta L Rev 841 at $853-54$

114 Supra note 112 at para 31.
} 
The situation of the Inuit with respect to arctic climate change seems best captured by a blend of Rotman's and Fox-Decent's theories. While it may be overstating the case to argue that the Inuit are being exploited, it seems fair to say that their interests have been compromised over several decades by rising energy consumption and the resultant emission of greenhouse gases. The Crown may need to act as protector of Inuit interests so that they are not completely sacrificed in favour of the industrial economy. Further, Fox-Decent's theory suggests that the Crown must take some measures to reconcile its control over energy and environmental policy with the limited sovereignty of the Inuit. In order to legitimate its own authority, the Crown must demonstrate that it has taken Inuit concerns into account.

\section{The Honour of the Crown}

A separate, but related concept to fiduciary obligations is the "honour of the Crown." connotes a prohibition on exploitation or sharp practice. For instance, in $R v$ Taylor and Williams, ${ }^{116}$ which involved a determination of the terms of treaty involving both oral and written provisions, the Ontario Court of Appeal wrote: "In approaching the terms of a treaty... the honour of the Crown is always involved and no appearance of 'sharp dealing' should be sanctioned." Perhaps the most important aspect of the honour of the Crown, however, is its foundational role in the duty to consult and accommodate when making decisions that affect Aboriginal interests.

The honour of the Crown was discussed at length in Haida Nation v British Columbia (Minister of Forests), ${ }^{117}$ where McLachlin CJC wrote, "while the Crown's fiduciary obligations and its duty to consult and accommodate share roots in the principle that the Crown's honour is engaged in its relationship with Aboriginal peoples, the duty to consult is distinct from the fiduciary duty that is owed in relation to particular cognizable Aboriginal interests." In Haida Nation, the Supreme Court found that the honour of the Crown governed situations where an Aboriginal right was asserted but not yet established. In such cases, the Aboriginal interest "is insufficiently specific for the honour of the Crown to mandate that the Crown act in the Aboriginal group's best interest, as a fiduciary...." ${ }^{118}$ Thus, the honour of the Crown is something less than a fiduciary duty, but helps to ensure that the Crown does not run roughshod over Aboriginal rights that have not yet been legally recognized. ${ }^{119}$ As Gordon Christie has explained,

\footnotetext{
115 See generally J Timothy S McCabe, The Honour of the Crown and its Fiduciary Duties to Aboriginal Peoples (Markham: LexisNexis Canada Inc, 2008). However, Rotman has argued that the honour of the Crown should not be "compartmentalized" from the Crown's fiduciary duty. Leonard I Rotman, "Crown-Native Relations as Fiduciary: Reflections Almost Twenty Years After Guerin" (2003) 22 Windsor YB Access Just 363 at 392 ["Crown Native Relations"]. 116 (1981), 34 OR (2d) 360 at 367 (CA) (MacKinnon JA).

117 [2004] 3 SCR 511 at para 54. See also Mikisew Cree First Nation v Canada (Minister of Canadian Heritage), [2005] 3 SCR 388 at para 51 (Binnie J) [Mikisew].

118 Haida Nation, ibid at para 18.

119 Ibid at para 27.
} 
The honour of the Crown was introduced as a proxy for fiduciary doctrine, imposing obligations on the Crown when it cannot be said that the Crown is exercising control over legal or practical interests....

The honour of the Crown is not a full surrogate, however, as the obligations on the Crown tied to its honour lie on a spectrum shifted down from those that might befall the Crown when it contemplates infringing an established Aboriginal right.

As with fiduciary duties, the honour of the Crown covers a spectrum of obligations from providing information to consultation and accommodation, depending on the nature and plausibility of the alleged Aboriginal interest, and the seriousness of the potentially adverse effects. ${ }^{121}$ In all cases, however, "the honour of the Crown requires that the Crown act with good faith to provide meaningful consultation appropriate to the circumstances." ${ }^{122}$ It thus provides both procedural and substantive rights.

In Haida Nation, the court explained how the process of consultation may lead to a determination that accommodation is necessary. McLachlin CJC wrote: "Where a strong prima facie case exists for the claim, and the consequences of the government's proposed decision may adversely affect it in a significant way, addressing the Aboriginal concerns may require taking steps to avoid irreparable harm or to minimize the effects of infringement, pending final resolution of the underlying claim." Although this does not give the Aboriginal group "veto" rights, it does require good faith efforts at compromise. There is, however, a notable distinction here between the honour of the Crown and its fiduciary duty. While the fiduciary duty requires the Crown to act in the best interests of the Aboriginal group, the honour of the Crown allows for a balancing of Aboriginal concerns against other societal interests. It is clearly a lesser form of protection.

The honour of the Crown may prove important to Inuit claims regarding climate change in the arctic. Although there are treaties that address natural resources and environmental assessment in arctic regions, it is not clear that they will give rise to specific fiduciary obligations with respect to climate change. In particular, using the language of Wewaykum, the Crown has not necessarily taken "discretionary control" in relation to a cognizable interest. Thus, the Inuit may be required to rely on the lesser obligations of the honour of the Crown to prevent their historical environment from being compromised by climate change. At the very least, this will require that the Crown engage in "meaningful consultation" with the Inuit. However, given the seriousness of the potential adverse effects on the Inuit - the destruction of their environment and subsistence culture - there is a strong argument that even more is required. Unless the Crown acts, there is a risk that their arctic environment will be permanently and severely damaged.

\footnotetext{
120 Gordon Christie, "Developing Case Law: The Future of Consultation and Accommodation" (2006) 39 UBC L Rev 139 at 159. 
As discussed below, the Crown's duty to consult and accommodate maps fairly neatly onto the twin prongs of climate change action: mitigation and adaptation. ${ }^{125}$ Even if the Crown is unable to mitigate the progress of climate change in the arctic, it can take important steps to accommodate the Inuit in adapting to their changing environment and preserving their distinctive culture as much as possible.

\section{The Scope and Content of the Crown's Fiduciary Obligation}

As indicated, the Crown's fiduciary obligation depends on the establishment of a cognizable interest over which the Crown has assumed discretionary control. Although this has not been litigated with respect to climate change, the most obvious sources of such an interest are the comprehensive treaties that have been negotiated regarding the various arctic regions. ${ }^{126}$ The 2005 Labrador Inuit Land Claims Agreement, for example, addresses the relevant issues of natural resources, water, fisheries, wildlife, and environmental assessment, and gives the Inuit priority and authority for the harvest of various animals and fish. Also, notably, Part 12.2.1 indicates that conservation and the Precautionary Approach should be priorities in any decision-making that affects wildlife and habitat in the region, and Part 14.5.1 provides for absolute liability when a developer causes loss or damage, present or future, to wildlife, fish, plants or aquatic plants and to any resulting loss of income.

Accordingly, the Inuit have some established rights with respect to the arctic natural environment and wildlife. The more difficult aspect of their claim would be to show that the Crown has assumed "discretionary control" over these interests. Indeed, a critical feature of the Agreement is the right to selfgovernment, ${ }^{127}$ and it includes measures for co-management of natural resources by the Nunatsiavut Government and the federal and provincial governments. ${ }^{128}$ The Inuit interests in the Agreement thus do not bear the hallmark vulnerability that typically characterizes the fiduciary relationship, nor do they create a position where the Crown can exercise discretion to the detriment of the Inuit.

Therefore, it cannot be straightforwardly established that the Agreement, in and of itself, gives rise to a fiduciary obligation on the part of the Crown. The Inuit may have to resort to other tests set out in the case law. For instance, given the Inuit's long history of subsistence hunting and fishing, and their close physical and cultural engagement with the arctic landscape, one assumes that they could establish that this subsistence lifestyle is a distinctive and integral part of their culture, as set out in Van der Peet. ${ }^{129}$ This may actually provide a more advantageous basis for the fiduciary obligation when it comes to the issue of climate change, as it can address a broader range of harms that extend beyond the

125 See United Nations Framework Convention on Climate Change, UNGA, 48th Sess, Supp No 49, A/Res/48/189 (1994).

126 See e.g., the James Bay and Northern Quebec Agreement (1975); the Inuvialuit Final Agreement (1984), the Nunavut Land Claims Agreement (1993), and the Labrador Inuit Land Claims Agreement (2005).

127 See Chapter 17 of the Labrador Inuit Land Claims Agreement, ibid.

128 For e.g., Parts 12.8 and 12.9 establishes the "Torngat Wildlife and Plants Co-Management Board" to, among other things, establish allowable harvests, conduct research respecting wildlife conservation, establish protected areas, and develop plans for reforestation and restocking of wildlife and plants.

129 Van der Peet, supra note 112. 
stipulations of any given agreement. At the same time, the lack of specificity may be fatal to proving a cognizable interest that creates obligations "in the nature of a private law duty," as required by Wewaykum.

But assuming that a relevant Aboriginal right could be established, what would the Crown's fiduciary duty entail? It is generally posited that fiduciary duties are proscriptive, rather than prescriptive. Fiduciary law tends to focus on actions that would be a breach of the duty of loyalty, such as a conflict of interest. It does not typically indicate what actions are necessary to promote the best interests of the beneficiary. ${ }^{130}$ As the English Court of Appeal wrote in Attorney-General $v$ Blake, ${ }^{131}$ fiduciary law "tells the fiduciary what he must not do. It does not tell him what he ought to do." This interpretation is consistent with the suggestion that it is for the fiduciary to determine how to exercise his or her discretion in serving the beneficiary's best interests. The courts will not generally instruct a fiduciary how to exercise this discretion. ${ }^{132}$

This proscriptive view of fiduciary law has been applied in some Aboriginal rights cases. For example, in Perry $v$ Ontario, ${ }^{133}$ the Ontario Court of Appeal suggested that the Crown's fiduciary obligation, embodied in section 35(1) of the Constitution Act, 1982, should operate as "a shield and not a sword. It is a restraint against regulation improperly affecting aboriginal rights, not an affirmative obligation to initiate negotiations with a view to such regulation." ${ }^{134}$ Under this view, the Crown has an obligation not to infringe Aboriginal rights, but not to take affirmative action to promote Aboriginal best interests. Indeed, most of the reported cases on the Crown's fiduciary obligation involve legislative or administrative actions that infringe on Aboriginal lands or the exercise of Aboriginal rights. ${ }^{135}$

However, this proscriptive characterization seems to be undercut by the Supreme Court's decisions in Delgamuukw $v$ British Columbia ${ }^{136}$ and Haida Nation. In Delgamuukw, an Aboriginal title case, Lamer CJ explained that Aboriginal title includes a right to choose how to use the land in issue, and that any infringement on that use requires justification by the Crown. At the very least, the Crown's fiduciary duty with respect to title includes a duty of consultation. Lamer CJ wrote,

the fiduciary relationship between the Crown and aboriginal peoples may be satisfied by the involvement of aboriginal peoples in decisions taken with respect to their lands. There is always a duty of consultation.... The nature and scope of the duty of consultation will vary with the circumstances. In

130 See PD Finn, "The Fiduciary Principle" in TG Youdan, ed, Equity, Fiduciaries and Trusts (Toronto: Carswell, 1989) at 28-29; and Matthew Conaglen, Fiduciary Loyalty: Protecting the Due Performance of Non-Fiduciary Duties (Oxford: Hart Publishing, 2010) at 202.

131 [1998] Ch 439 at 455 (CA).

132 See generally Re Hastings-Bass, [1975] Ch 25 (CA); Fox v Fox Estate (1996), 28 OR (3d) 496 (CA).

133 (1997), 33 OR (3d) 705 (CA).

134 Ibid at 733

135 See Rotman, “Crown Native Relations", supra note 115 at 368.

136 [1997] 3 SCR 1010. 
occasional cases, when the breach is less serious or relatively minor, it will be no more than a duty to discuss important decisions that will be taken with respect to lands held pursuant to aboriginal title. Of course, even in these rare cases when the minimum acceptable standard is consultation, this consultation must be in good faith, and with the intention of substantially addressing the concerns of the aboriginal peoples whose lands are at issue. In most cases, it will be significantly deeper than mere consultation. Some cases may even require the full consent of an aboriginal nation, particularly when provinces enact hunting and fishing regulations in relation to aboriginal lands. ${ }^{137}$

This makes it relatively clear that the Crown would have an obligation to consult with the Inuit regarding actions that might affect the arctic environment. There is an affirmative obligation to, at least, initiate negotiations. Indeed, even if the Inuit cannot establish a sufficiently specific right to ground a fiduciary duty, they can invoke the lesser obligation of honour of the Crown, which also requires a minimum level of consultation. This would additionally be consistent with treaty obligations, such as the Labrador Inuit Land Claims Agreement, which requires consultation with the Nunatsiavut Government before Canada agrees to be bound by an international agreement or takes a position before an international tribunal that may affect a right under the Land Claims Agreement. ${ }^{138}$

Regardless of the scope of conventional fiduciary duties, the Canadian courts have routinely described the Crown's obligation toward Aboriginal peoples as sui generis, and have suggested that affirmative measures may be required in some circumstances. For instance, in Alexander Band No 134 v Canada (Minister of Indian Affairs and Northern Development), ${ }^{139}$ Strayer J of the Federal Court opined that the Crown's fiduciary duty may even require the government to enact legislation. This is contrary to the general principle that a failure to legislate is not actionable in the courts. Strayer J explained that this "excellent principle, while no doubt generally sound, may sometimes have to give way in light of the decision in the Guerin case." ${ }^{140}$ Although the statement was obiter, and referred to the Crown's obligations when dealing with surrendered land, it at least suggests that the Crown's fiduciary obligation does not follow the strictly proscriptive model.

Moreover, the Canadian courts have found that section 35(1) of the Constitution Act, 1982 should be construed purposively. In Sparrow, for example, the Supreme Court stated, "When the purposes of the affirmation of aboriginal rights are considered, it is clear that a generous, liberal interpretation of the words in the constitutional provision is demanded." ${ }^{141}$ This purposive interpretation suggests that the Crown's fiduciary duty may encompass affirmative obligations to

137 Ibid at para 168.

138 Supra note 126, part 17.27.

139 [1991] 2 FC 3.

140 Ibid at para 17. The plaintiffs had alleged that the government's failure to enact certain regulations at a particular time led to a significant loss of oil revenue from surrendered lands. Their claim was ultimately dismissed.

141 Sparrow, supra note 86 at 1106. 
protect Aboriginal interests. Thus, in Eastmain Band $v$ Canada (Federal Administrator), ${ }^{142}$ the Federal Court of Appeal adopted the words of Cooke $\mathrm{P}$ in New Zealand Maori Council v Attorney-General: "the duty of the Crown is not merely passive but extends to active protection of Maori people in the use of their lands and waters to the fullest extent practicable." ${ }^{143}$ Rotman has suggested that the Crown's fiduciary obligation should thus be placed within the category of prescriptive duties: "In addition to being required to positively exercise a power where its exercise is in their beneficiaries' best interests, where fiduciaries possess the power to contravene their beneficiaries' best interests, they are bound not to exercise those powers." ${ }^{144}$

A broad interpretation of the Crown's fiduciary obligations is also supported by the historical tradition of protecting Aboriginal peoples from exploitation. This dates back to the Royal Proclamation of 1763 and the concept of surrender, as discussed in Guerin. The preface to the surrender provisions in the Royal Proclamation indicates that "great Frauds and Abuses have been committed in purchasing Lands of the Indians, to the great Prejudice of our Interests, and to the great Dissatisfaction of the said Indians." 145 By requiring Aboriginals to surrender their lands to the Crown, rather than deal with third parties directly, the Crown assumed a responsibility to promote their best interests and protect them from being exploited by European settlers. While the arrangement now seems rather paternalistic, there is room to modernize and extrapolate from this principle in the context of climate change. As indicated, the Inuit are among those least responsible for climate change, yet among those most vulnerable to its negative effects. In other words, they are being unfairly prejudiced by the actions of energy producers and other industries that disproportionately affect the arctic environment. Based on its historical tradition and assumption of responsibility, the Crown may therefore be required to take some action to prevent the Inuit's interests from being sacrificed by the industrial economy.

Finally, the Canadian courts have sometimes been willing to frame fiduciary duties in terms of affirmative obligations in other areas. For example, in $M(K) v M$ $(H){ }^{146}$ the Supreme Court of Canada described the parent-child relationship as fiduciary, requiring parents to "care for, protect and rear their children." in McInerney $v$ MacDonald, ${ }^{148}$ the Supreme Court found that the fiduciary nature of the physician-patient relationship required the physician to grant the patient access to information used in administering treatment. Although limited to relatively narrow circumstances, these cases suggest a willingness by Canadian

142 [1993] 1 FC 501 (CA).

143 [1987] 1 NZLR 641 at 664, cited in Eastmain Band, ibid at 518. Cooke P explained that the relationship between the Crown and Maori in the case created responsibilities "analogous to fiduciary duties."

144 Rotman, Parallel Paths, supra note 92 at 263 (emphasis added).

145 Royal Proclamation of 1763, supra note 78, quoted in Guerin, supra note 76 at 382.

146 [1992] 3 SCR 6.

147 Ibid at 62. Nevertheless, the breach of the fiduciary obligation in that case was incest, which is clearly a proscribed activity rather than failure to perform a prescribed one.

148 [1992] 2 SCR 138 at 150. 
courts (unlike their Commonwealth counterparts ${ }^{149}$ ) to take a broad view of fiduciary duties, including both the imposition of affirmative obligations and the protection of non-financial interests.

According to the above principles, it is possible that the Crown could be liable for breaching its fiduciary duty not only for taking action that is harmful to the best interests of the Inuit, but also for failing to take action to facilitate their best interests. Given the risks to life and health that are implicated by climate change in Canada's arctic, a persuasive case can be made that the Crown is in breach of its fiduciary obligations if it omits to take action, for example, to implement the terms of the Kyoto Protocol or otherwise mitigate climate change, or to assist the Inuit in the process of adaptation.

\section{E. The Fiduciary Doctrine and Aboriginal Culture}

The fiduciary doctrine may be particularly important if the Inuit wish to claim that climate change is threatening their culture. As discussed in the first sections of this article, climate change is interfering with the Inuit's ability to practice their traditional subsistence lifestyle. Key food sources are being depleted, and hunting has become more dangerous and unpredictable. In some situations, communities may be forced to relocate due to coastal erosion and flooding. This poses a threat not only to Inuit life and health, but also to their cultural survival. Inuit culture is inextricably linked to the arctic environment. As Tsosie explains:

destruction of indigenous land-bases would result in destruction of indigenous groups who understand themselves as culturally distinctive and rooted in the land. This understanding is shared by each member of the group as an individual, as well as by the entire group as a collective. Based on this understanding, the group maintains an ethical view of itself in relation to the land, and it is this ethical view that perpetuates each generation of tribal members, as a cultural group. Thus, to take that group's land would strip the group of its understanding of itself and destroy the opportunity of the members to belong to the larger unit and share in collective understanding. ${ }^{150}$

However, the Inuit's claims for compensation for loss of culture in the environmental or climate change context have so far met with resistance. For example, in In re Exxon Valdez, ${ }^{151}$ discussed above, the loss of subsistence fishing was not seen as sufficiently "special" damage to distinguish the Inuit from other Alaskans for the purposes of a public nuisance claim. Similarly, despite abundant evidence on the negative cultural impacts of global warming, the petition of the Inuit Circumpolar Conference to the Inter-American Commission on Human Rights did not even result in a ruling. ${ }^{152}$

149 See especially Breen $v$ Williams (1996), 186 CLR 71 (HCA), where the court was highly critical of the Canadian approach to fiduciary obligations, noting that it was characterized by "assertion rather than analysis" at 95 .

150 Tsosie, supra note 1 at 1656-57.

151 Supra note 50.

152 See supra notes 53-67 and accompanying text. 
Inuit claims for cultural harm may have more traction if framed in terms of the Crown's fiduciary duty. Such cultural claims are not without precedent in Canadian law. In Lafrance Estate $v$ Canada (Attorney General), ${ }^{153}$ the Ontario Court of Appeal refused to strike out a claim by the children of those who were forcibly removed from their families to be educated in residential schools. The court indicated that, by implementing the residential school policy (which was allegedly designed to assimilate Aboriginal children to European culture), the Crown assumed a fiduciary duty with respect to the education of those children. Further, in finding that the Crown's fiduciary duty may have extended to the descendents of those taken to residential schools, the court isolated the essence of their claim as an allegation that the purpose of the residential school policy was to strip Aboriginal children of their culture and identity, thereby preventing them from passing on their spiritual and cultural practices to future generations. ${ }^{154}$ The decision in Lafrance suggests that the Crown may thus owe a fiduciary duty not only to the Inuit who are currently threatened by climate change, but also to successive generations to whom fundamental cultural traditions may be lost. ${ }^{155}$

One of the underlying purposes of section 35(1) of the Constitution Act, 1982 is to preserve Aboriginal culture: the section is primarily invoked to protect practices that are integral to the claimant's distinctive culture. ${ }^{156}$ This need not be limited to government actions that directly infringe on cultural practices. For instance, Michael Coyle has argued that the Crown's fiduciary obligation "includes the duty to preserve a space for the preservation of Aboriginal culture." ${ }^{157}$ Coyle views this duty as an aspect of shared sovereignty and consistent with the inherent right of self-government of Aboriginal peoples. He suggests that the Crown has an obligation to help develop and maintain institutions by which Aboriginal peoples can preserve their languages, cultures, and other distinctive characteristics. Because the mechanisms necessary to preserve these characteristics existed prior to European contact and have not been expressly extinguished, Coyle argues that they are among the Aboriginal rights that were "recognized and affirmed" in section 35(1) of the Constitution Act, $1982 .{ }^{158}$

The application of fiduciary doctrine to Inuit cultural claims is strengthened by the inseparability of Inuit culture and the natural environment. Although the Crown's fiduciary obligation is not limited to its dealings with Aboriginal lands, the "trust-like" character of the relationship underlines the value of land in both the historical and contemporary duties of the Crown. Many Aboriginal rights are defined by their practice in a particular geographical region. In the case of the Inuit, the loss of the arctic environment would effectively destroy their distinctive culture. Thus, the Crown may have an obligation to preserve the environment not for its own sake, but as the essential locus of the Inuit's cultural traditions.

\footnotetext{
153 (2003), 64 OR (3d) 1 (CA).

154 Ibid at para 35

155 For a discussion of cultural claims relating to the residential school system, see Joseph Eliot Magnet, Litigating Aboriginal Culture (Edmonton: Juriliber, 2005).

156 See Sparrow, supra note 86 and Van der Peet, supra note 112.

157 Michael Coyle, supra note 113 at 857.

158 Ibid at 858.
} 


\section{SUMMARY AND CONCLUSIONS}

The above analysis suggests that a plausible argument can be made that the Crown owes a fiduciary obligation to the Inuit to take some action to mitigate climate change in the arctic. The threats to Inuit life and health are sufficiently severe to invoke the Crown's protection; moreover, there is a risk that distinctive cultural traditions will be lost along with the arctic environment. At the very least, the honour of the Crown is implicated in any decision relating to climate change that would negatively affect Inuit interests. Canada's economic and industrial interests cannot be used as an excuse to "run roughshod" over their rights.

Of course, at the rate that climate change is occurring in the arctic, it is unrealistic to expect that the Crown will be able to make significant progress in terms of mitigation. Indeed, given that the nations most responsible for greenhouse gas emissions are the United States and China, and that Canada produces less than $2 \%$ of the world's emissions, ${ }^{159}$ the Canadian government has limited ability to slow the progress of global warming. Thus, climate change in Canada's arctic regions is inevitable. ${ }^{160}$ This means that Canada's energies are probably best focused on helping the Inuit to adapt to their changing environment. Climate change researchers have recently argued for the prioritization of adaptation over mitigation, as it will reduce Inuit vulnerability to climate change and, in some instances, help them to take advantage of the new opportunities presented by a warming arctic. ${ }^{16}$

It is beyond the scope of this article to suggest what adaptation measures should currently be promoted in the arctic. There is a wide range of available options. For example, new safety equipment and technology (eg radios, satellite phones) may help to minimize the risk to hunters in uncertain weather conditions. In addition, better and more comprehensive weather forecasting is required to assist hunters in planning expeditions. ${ }^{162}$ On the positive side, the longer ice-free season provides the opportunity to use boats to engage in fishing or to reach other hunting grounds. Further, the reductions in polar bear and ringed seal populations may be offset by animals like harp seals, narwhal and beluga whales, which are now in greater abundance and availability due to warmer temperatures and longer summers. ${ }^{163}$ However, the new modes of transport (boats, ATVs, etc) and communications technology are not inexpensive, and hunting different species

159 See "World carbon dioxide emissions data by country: China speeds ahead of the rest" The Guardian (31 January 2011), online: Guardian Unlimited <http://www.guardian.co.uk/news/datablog/2011/jan/31/world-carbon-dioxide-emissionscountry-data-co2\#data>.

160 See V Ramanathan \& Y Feng, "On avoiding dangerous anthropogenic interference with the climate system: Formidable challenges ahead" (2008) 105 Proceedings of the National Academy of Sciences 14245.

161 See e.g., James D Ford, "Dangerous climate change and the importance of adaptation for the Arctic's Inuit population" (2009) 4 Environment Research Letters 1; James D Ford, Tristan Pearce, Frank Duerden et al, "Climate change policy responses for Canada's Inuit population: The importance of and opportunities for adaptation" (2010) 20 Global Environmental Change 177; JB Ruhl, "Climate Change Adaptation and the Structural Transformation of Environmental Law" (2010) 40 Envtl L 363.

162 Ford et al, ibid at 185-86.

163 George W Wenzel, "Canadian Inuit subsistence and ecological instability - if the climate changes, must the Inuit?” (2009) 28 Polar Research 89. 
may require different or additional tools, which are beyond the immediate financial means of traditional subsistence hunters. ${ }^{164}$ Thus, it may be necessary to provide financial assistance to individuals or communities in order to ease their transition to new hunting methods.

In terms of the Crown's honour and fiduciary duty, the process of adaptation pairs nicely with the obligation to consult and accommodate the Inuit when their interests are at stake. Given the significant risks posed by climate change to Inuit life, health and culture, the Crown may well be obliged to pursue accommodation measures. Fortunately, both the federal and territorial governments have initiated adaptation research, consultation and policies with respect to arctic climate change. ${ }^{165}$ For example, the Government of Nunavut has established an adaptation plan, ${ }^{166}$ which included enhanced governmental and private sector partnerships, regional workshops, research and vulnerability analyses, and pilot projects in the territory's major centres. ${ }^{167}$ However, most of the projects remain in the consultative and planning stages, ${ }^{168}$ so it may become necessary to prod the government into effective action. The Crown's fiduciary obligations may provide a useful framework for encouraging and, if necessary, litigating the issue of adaptation.

As suggested in the introduction to this article, the Inuit are uniquely placed in terms of climate justice. They are a sympathetic group of plaintiffs, whose lives and culture are seriously threatened by climate change, and who have historically suffered from poverty and political disadvantage. Yet, their attempts to achieve compensation or other action on climate change have so far been unsuccessful both in tort and international law. Fortunately, the Inuit in Canada are also uniquely placed in terms of the framework of the Crown's recognized fiduciary obligation toward Aboriginal peoples. Where significant interests are at stake, the Crown's honour and fiduciary obligation may apply so as to require a minimum degree of consultation and accommodation.

Indeed, the legal framework in Canada may provide the "perfect storm" for litigation on arctic climate change. As discussed above, the Canadian courts have been exceedingly willing to recognize new and broad fiduciary relationships in a variety of legal settings, even apart from the sui generis fiduciary duty owed by the Crown to the Inuit. ${ }^{169}$ This expansive approach has been criticized and rejected abroad, where fiduciary relationships are limited primarily to situations involving

164 See Ford et al, supra note 161 at 184.

165 See generally, Mark Brooks et al, Prioritizing Climate Change Risks and Actions on Adaptation:

A Review of Selected Institutions, Tools, and Approaches (Ottawa: Government of Canada, Policy Research Initiative, 2009).

166 Department of the Environment, Setting the Course: Climate Change Impacts and Adaptation in Nunavut (Upagiaqtavut) (Iqualuit: Government of Nunavut, 2010).

167 These include Clyde River, Hall Beach, Kugluktuk, Cambridge Bay, Arviat, Whale Cove and Iqaluit. The pilot programs are a collaborative effort involving the Government of Nunavut, the Canadian Institute of Planners, Indian and Northern Affairs Canada, and Natural Resources Canada.

168 See e.g., the adaptation plan for the Hamlet of Arviat focuses on information gathering and the appointment of a "Climate Change Adaptation Coordinator" to oversee next steps. See Michael Sullivan \& Karen Nasmith, Hamlet of Arviat - Climate Change Adaptation Action Plan (Arviat: Canadian Institute of Planners, 2010) at 15.

169 See e.g., $M(K) v M(H)$, supra note 146 (incest between parent and child); and Norberg $v$ Wynrib, [1992] 2 SCR 226 (doctor extorting sexual favours from a drug-addicted patient). 
financial interests. ${ }^{170}$ Thus, Canada may be the only jurisdiction where a claim based on fiduciary duty may be raised in the context of climate change.

In an ideal world, climate change and its negative effects on the Inuit population would be comprehensively addressed through political channels. And while there is some reason for optimism, particularly in terms of adaptation plans, it is an unfortunate reality that litigation is sometimes necessary to spur the government into action or at least get issues in the political spotlight. ${ }^{172}$ The Crown's fiduciary obligation toward Aboriginal peoples provides a promising conceptual framework for addressing the legal issues surrounding climate change in Canada. By combining aspects of land management, respect for traditional rights, and cultural protection, the Crown's fiduciary duty may provide the best chance at achieving climate justice for Canada's Inuit.

170 See especially Breen $v$ Williams, supra note 149.

171 While beyond the scope of this article, framing a case in terms of fiduciary duty has other practical advantages. Because it is an Equitable obligation, the Common Law's strict rules of causation and remoteness do not apply. This may assist in overcoming some of the barriers that have typically hampered climate change litigation.

172 The precise mechanics of such litigation raise additional issues that are beyond the scope of this article. For instance, if it is found that the Crown breached its fiduciary obligations, what types of damages would be available? Alternatively, if the Inuit seek action by the Crown, how might a mandatory injunction be crafted? 